\title{
Implementation of Blockchain Technology in Learning Management System (LMS)
}

\author{
Untung Rahardja ${ }^{1}$, Qurotul Aini ${ }^{2}$, Alfiah Khoirunisa ${ }^{3}$, \\ Po. Abas Sunarya ${ }^{4}$, Shofiyul Millah ${ }^{5}$ \\ $\mathbf{1 , 2 , 3 , 5}$ University of Raharja \\ ${ }^{4}$ Universitas Pasundan \\ 1,2,3,5 Modern, Jl. Jenderal Sudirman No.40, RT.002/RW.006, Cikokol, Kec. Tangerang, Kota \\ Tangerang, Banten 15117 \\ ${ }^{4} \mathrm{Jl}$. Lengkong Besar No. 68, Bandung \\ e-mail: Untung@raharia.info ${ }^{1}$, Aini@raharia.info ${ }^{2}$, alfiah@raharia.info ${ }^{3}$, \\ abas@raharja.info ${ }^{4}$, shofiyul@raharja.info ${ }^{5}$
}

To cite this document :

Rahardja, U., Aini, Q., Khoirunisa, A., Sunarya, P.A \& Millah, S. (2022). Implementation of Blockchain Technology in Learning Management System (LMS). Aptisi Transactions on Management (ATM), 6(2), 112-120.

DOI :

https://doi.org/10.33050/atm.v6i2.1396

\begin{abstract}
It is well known by the public that the development of science and technology has progressed very rapidly and even continues to increase from year to year, especially in the education system. But in reality, there are still many learning systems that use conventional methods. This method makes the learning process passive and inactive. But now by implementing blockchain into the online learning process and there is no conventional learning process that makes learning activities boring and technology-saturated in the educational learning system at Raharja University, making the learning process more effective and efficient. The objectives of using blockchain technology in education include developing educational curricula, improving the use of educational applications, processing data about education. The research method is carried out by collecting data and using the literature study. So that the presence of blockchain technology makes the education system at the forefront. This application is done so that the learning system can be done with easy access, without being limited by space and time so that it is more efficient. It can even motivate to increase exploration in the learning process which in turn will increase student productivity, of course.
\end{abstract}

Keywords: Blockchain, Educations, Technology, Learning, Applications System

\section{Introduction}

One technology currently undergoing development is blockchain technology, where a digital transaction record based on its structure is linked together in a chain. Through this blockchain technology, blockchain has a database that other people cannot manipulate. The main advantage of blockchain is to make transactions safely without the intervention of third parties. Negligence of third parties can reduce processing costs while increasing transaction efficiency. Blockchain technology offers a system for sharing information that is safe and reliable because it records all transactions that occur permanently and then is spread across the entire blockchain network. Various problems regarding data can be overcome with blockchain technology. By using blockchain technology now the education system can be monitored with ease and trustworthiness, now many online learning based on blockchain technology [1]. In Indonesia now has begun to experience changes in all fields that have been supported by technology, especially in the world of education, which has changed so dramatically with the abandonment of the process of learning methods that still use conventional methods so that it becomes boring and saturated learning activities [2]. 
work is licensed under a Creative Commons Attribution-ShareAlike 4.0 International License. 

With methods like this students will feel bored so that they become lazy and do not pay attention to the learning process. However, a better llearning learning model can improve students' understanding of the material concepts of each lesson so as to get improved learning outcomes [3]. With the technology offered to make various industries interested in especially the world of education to implement the blockchain, in a new learning method by increasing student motivation in the learning process, student enthusiasm and motivating to increase exploration in the learning process which in turn will increase student productivity of course [4] [5]. And also explains about blockchain-based digital payment schemes [6] [7] [8].

\section{Research Method}

This research is based on qualitative methods, namely by giving meaning in depth to the facts or data available. This method has been chosen because the topic of blockchain itself is still a very new trend in this domain. In addition, this approach shows the most recent subject in the domain proposed by other researchers. This approach is used because this research aims to describe or explain the data and facts of existing conditions, as well as to conduct an analysis of what needs to be done to achieve the desired conditions in the future. This research is based on an actual qualitative method using a literature review. In addition, this approach shows the most recent subject in the domain proposed by other researchers. The method used in this research is descriptive research method which is a research method that explains an object in accordance with existing conditions without changing it. The place of this research is placed in the Raharja College with the object of research is the application of blockchain technology in learning learning which is currently being used to support the industrial era 4.0. The higher the level of education the higher the welfare of life that can be achieved. There are many methods that can be used in an online learning activity, one of which is the iLearning learning method used at Raharja College.

In research conducted by Untung Raharja, Qurotul Aini, Ariesanti, and Alfiah Khairunisa in 2018, iLearning method (Integrated Learning) online learning system that uses IPAD that makes students learn more easily and effectively. In the llearning method the facility is given in the form of an official campus email which is Rinfo which is used as a communication medium, which can be seen in terms of its security by preventing anyone from outside the Raharja College to carelessly access the 10 Pillars of IT (Ten Pillar IT i Learning) at Raharja College [16]. iDu (iLearning Education) is an online iLearning learning system at Raharja College. Through iDu, students can interact with lecturers and fellow students anywhere and anytime. This research was conducted by Untung Raharja, Qurotul Aini, Ariesanti, and Alfiah Khairunisa in 2018. With the application of blockchain technology in the form of learning in the form of games or quizzes that can help students to get additional points in the form of SC (Special Contribution) so that students have the motivation to be more active in doing assignments and can maximize learning and make the learning and teaching process more enjoyable [10] [11] [12]. One of the storage media for iLearning lectures used at Raharja University is in the form of ibooks where the iLearning learning method is in the form of material related to courses at Raharja College, iBooks have been installed on iPad for lecturers and students in the form of documents and other PDF. In the past, lecture bills paid by students conventionally had to exchange payment receipts for a receipt [13]. So the information received is not accurate and realtime. However, blockchain will promote efficiency improvements in the banking industry [14]. So now in Raharja College there is GO + which is used by Raharja students to make the payment process for lectures. So that Raharja students can easily find out the details of fees and information due for payment. If a student has made a payment that has been paid then there will be a notification from an email notifying that the student has paid off in the payment process [15]. Besides GO +, there is also Raharja Internet Cafe (RIC) which is a service that will help Raharja students in the lecture process. In this RIC provides many student needs such as iPad, Tab and laptop accessories. This application has a sales website that uses e-commerce to facilitate the admin in recording purchases. Even Raharja University also has an online rating system, the system is called PEN + (Assessment Plus), where all forms of student value input activities can be carried out anywhere and anytime, which makes the input of these values can be done efficiently. So now many online learning processes are based on blockchain technology [16] [17]. 
Research conducted by Turkanovic, M Holbl, Kosic,K ,Hericko, M. and Kamisalic, A. years 2018 in their journal titled EduCTX, a system that utilizes blockchain, namely as a decentralized architecture, which is transparent and transparent. aims to create higher education accreditation globally [18]. However, a better llearning learning model can improve students' understanding of the material concepts of each lesson so as to get improved learning outcomes [19. And research conducted by Zikratov, I., Kuzmin, A., Akimenko, V., Niculichev, V., \& Yalansky, L. years 2017 in the world of education investigating blockchain activity in terms of how to store, retrieve, and share files decentralized network [20].

\section{Results and Analysis}

Before entering the industrial era 4.0 the learning process in Indonesia was still a lot of media used that had not been computerized and were not yet online or also called conventional learning methods, so that there were still many learning processes using conventional methods, it made the information published less effective and efficient [21]. With this conventional method, students must have a lot of books for the learning process and even the collection of assignments is still by giving sheets of assignments to be given to lecturers [22]. With this conventional method requires students to ask questions directly to the teacher, causing students to become passive, with the application of conventional learning methods that are still very abstract and theoretical learning methods that make students more easily stressed and bored [23]. With this conventional method requires students to ask questions directly to the teacher, causing students to become passive

[24].

\section{A. Problem Analysis}

On the issues raised above, that this blockchain technology offers concepts that have never existed before. If usually all information is stored in one digital ledger on the server, blockchain offers a decentralized system.

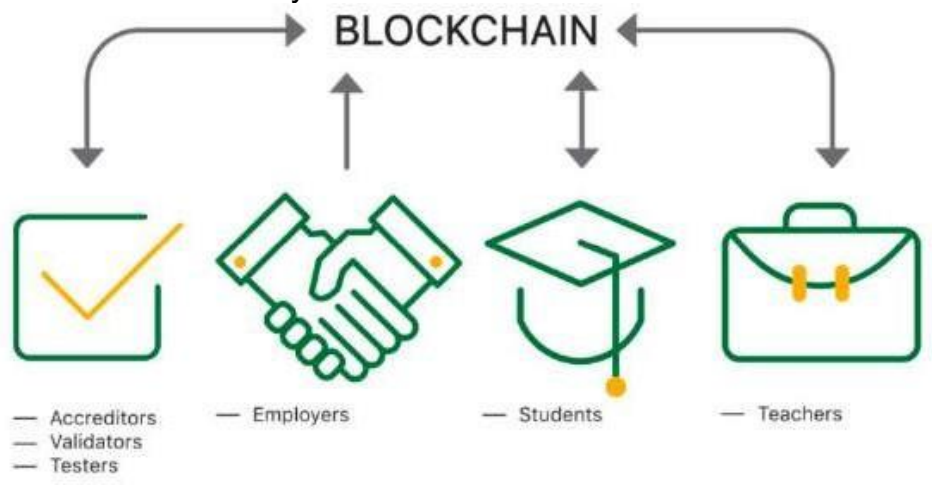




\section{B. Problem Solving}

Now with the blockchain technology that has been applied in the world of education, it has the advantage of a decentralized system and strong cryptography that can even assist universities in building infrastructure in archival storage in the form of transcripts, certifications and diplomas. Therefore by utilizing blockchain technology, it will create a safe and reliable data storage server, so that at present many digital or online learning methods. In the learning method that is done online, not only can access knowledge from books, but students can also access learning material anywhere and anytime, so that makes student time efficient and effective [25].

C. Implementation

1. Display Email Rinfo

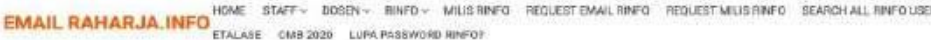
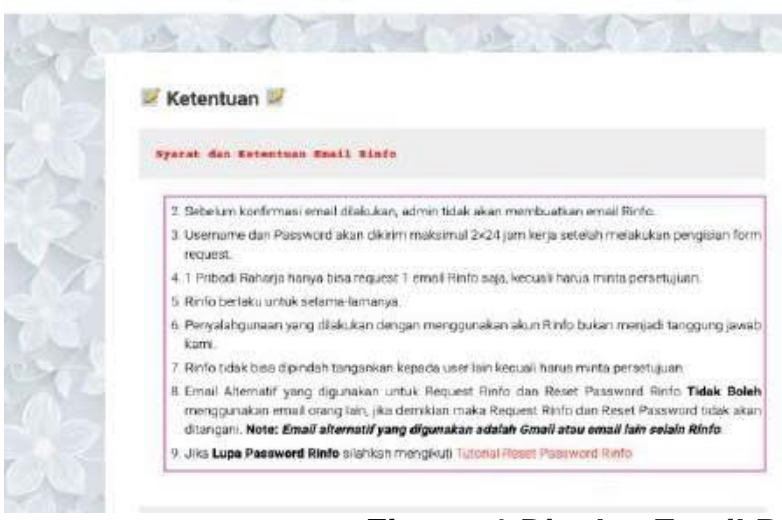

\section{REQUEST RINFO ?}

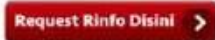

TUTORIAL RINFO

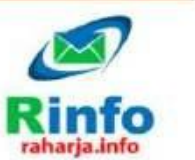

Figure. 1.Display Email Rinfo

Rinfo Email is an email service owned by Raharja University. This Rinfo email will be used by Raharja students during the learning process. So by using this email students can communicate well wherever and whenever. 
2. Display logins on iDu

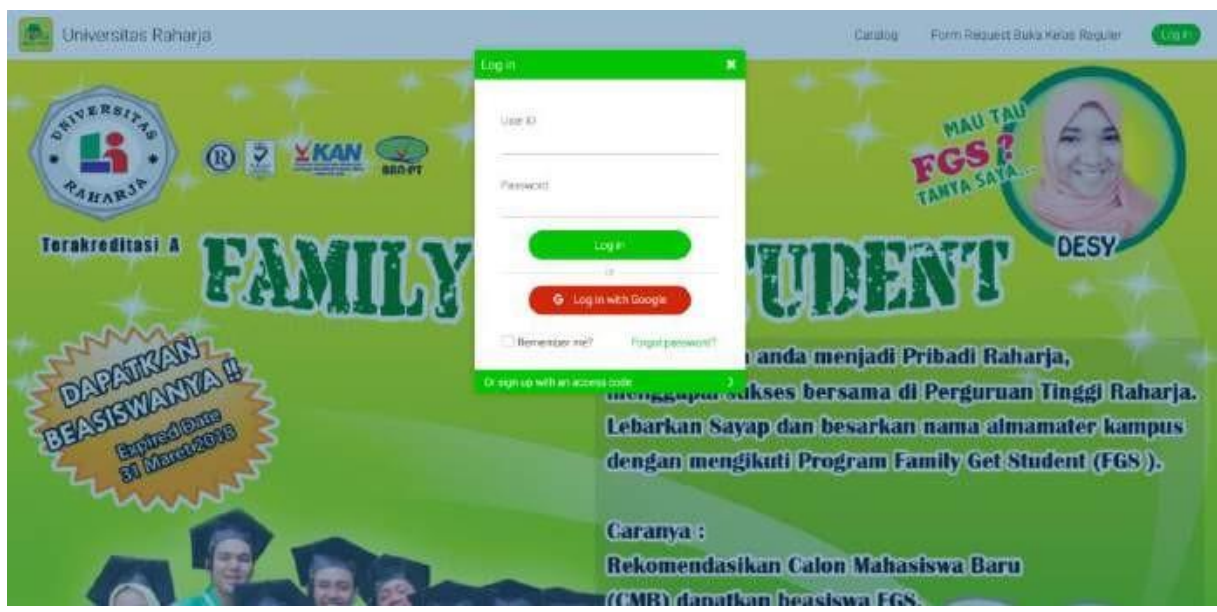

Figure. 2. Display logins on iDu

In the picture above is the home display on iDu (iLearning Educations) where users who want to enter must use the official campus email that is Rinfo given by Raharja College.

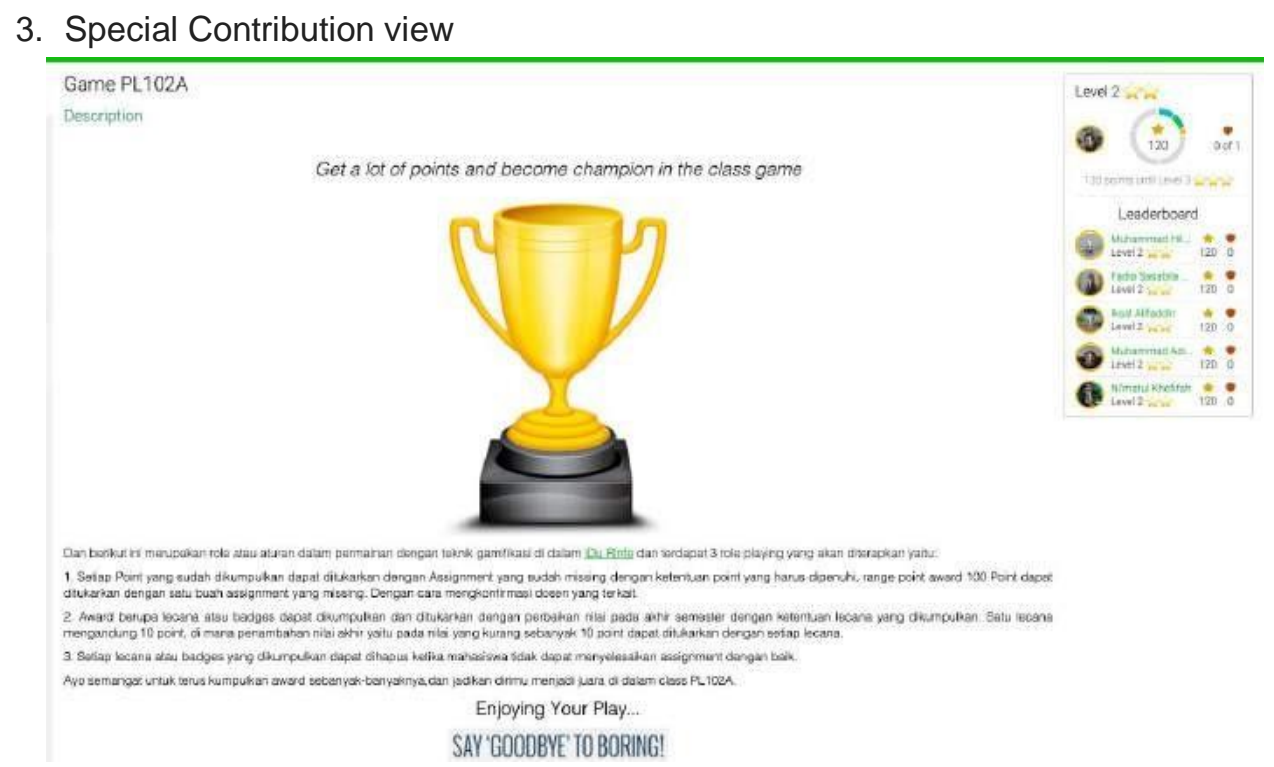

Figure. 3. Display of students who get SC (Special Contribution)

In the picture above is the iDu (iLearning Educations) display where users who want to enter must use the Rinfo email, which is the official campus email. During the learning process, the lecturer provides SC (Special Contributions) for students who are active in the learning process in class. This SC is given so that students are even more enthusiastic in learning. 
4. Display levels of iDu

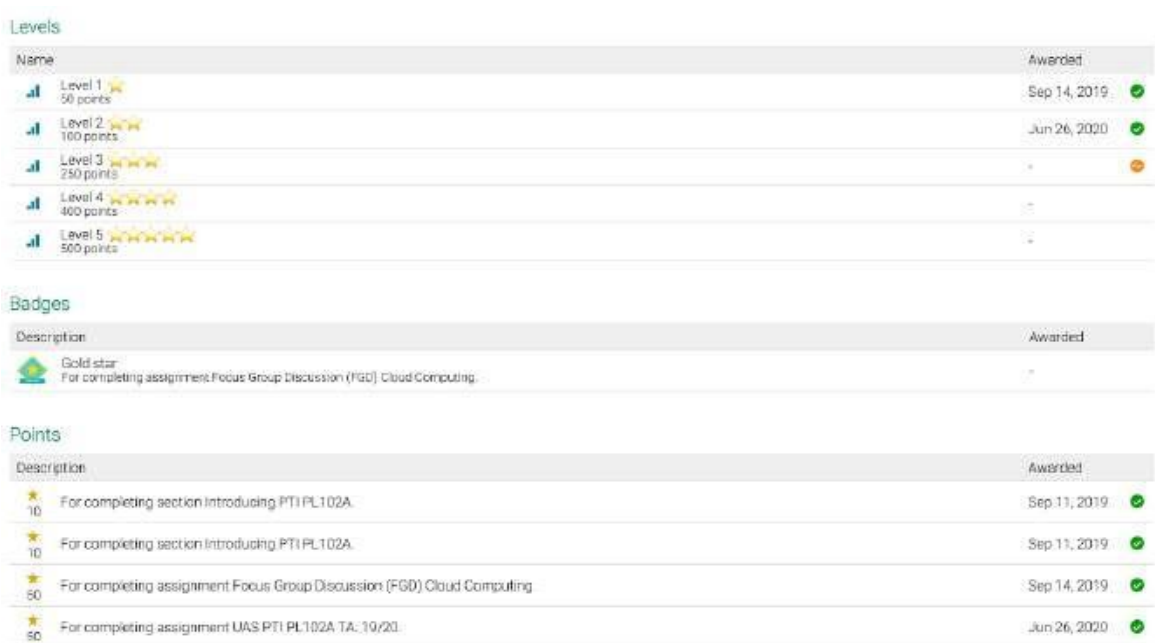

Figure. 4.Display levels of iDu (iLearning Educations)

The display in the picture above is the point level display level on iDu (iLearning Education) that is obtained by students if they successfully pass this level.

5. Listing Program

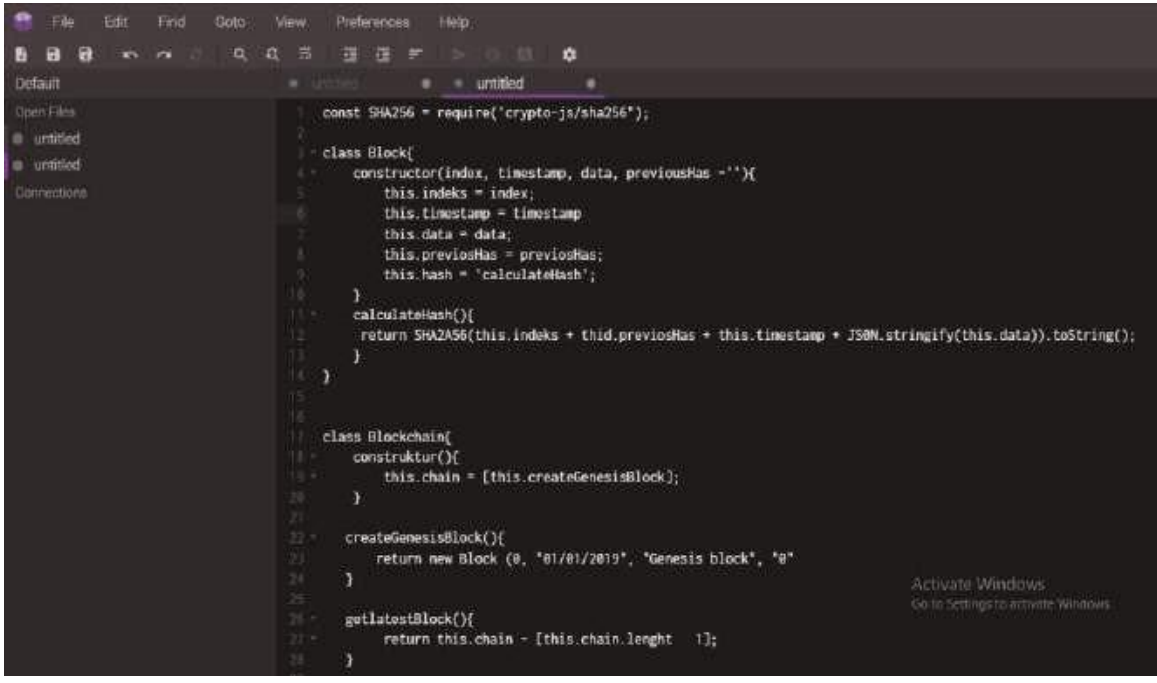

Figure. 5. Display blockcerts script on iDu (iLearning Educations ) 


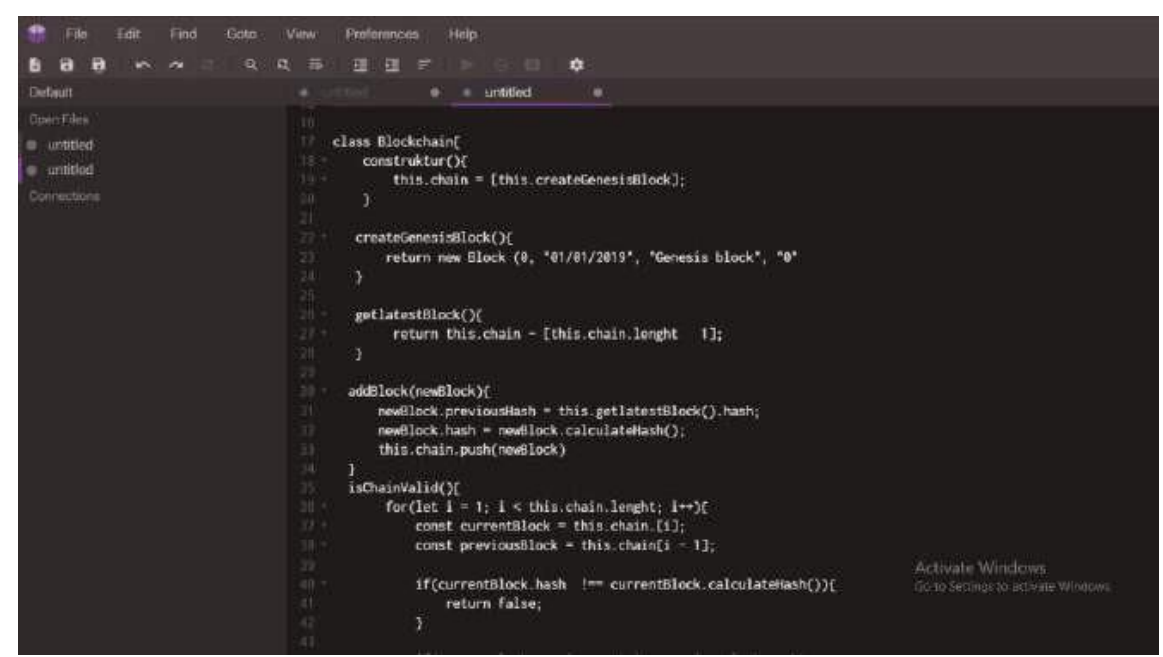

Figure. 6. Display blockcerts script on iDu (iLearning Educations )

\section{Conclusion}

Based on the discussion above, namely the Application of Blockchain Technology in the Learning Management System at Raharja University, the research authors can provide conclusions, namely. The benefits of Blockchain technology in the Learning Management System at Raharja University, can enable students in a new world of education. Students can access lecture learning materials more easily. With this Blockchain technology, it makes a quality Learning Management System at Raharja University. That is, blockchain technology can help improve the old data education management system model and bring education to Raharja University. 


\section{References}

[1] Al HARTHY, K., Al SHUHAIMI, F., \& Al ISMAILY, K. K. J. (2019, January). The upcoming Blockchain adoption in Higher-education: requirements and process. In 2019 4th MEC International Conference on Big Data and Smart City (ICBDSC) (pp. 1-5). IEEE.

[2] AINI, Q., RAHARDJA, U.,SUPRIYATI, R., \& KHOIRUNISA, A. (2019). Pengaruh Mailing Groups Sebagai Media Diskusi Dalam Motivasi Belajar Mahasiswa. JURNAL MEDIA INFORMATIKA BUDIDARMA, 3(1), 24-29.

[3] BAHGA, A., \& MADIS, V. K. (2016). Blockchain platform for industrial internet of things. Journal of Software Engineering and Applications, 9(10), 533.

[4] DABBAGH, M., SOOKHAK, M., \& SAFA, N. S. (2019). The evolution of blockchain: A bibliometric study. IEEE Access, 7, 19212-19221

[5] GUO, Y., \& LIANG, C. (2016). Blockchain application and outlook in the banking industry. Financial Innovation, 2(1), 24.

[6] HU, Y., MANZOOR, A., EKPARINYA, P., LIYANAGE, M., THILAKARATHNA, K., JOURJON, G., \& Seneviratne, A. (2019). A Delay-Tolerant Payment Scheme Based on the Ethereum Blockchain. IEEE Access, 7, 33159-33172.

[7] MENG, W., TISCHHAUSER, E. W., WANG, Q., WANG, Y., \& HAN, J. (2018). When intrusion detection meets blockchain technology: a review. leee Access, 6, 10179-10188.

[8] PERDANI, M. D. K., WIDYAWAN, W., \& SANTOSA, P. I. (2018). BLOCKCHAIN UNTUK KEAMANAN TRANSAKSI ELEKTRONIK PERUSAHAAN FINANCIAL TECHNOLOGY (STUDI KASUS PADA PT XYZ). SEMNASTEKNOMEDIA ONLINE, 6(1), 1-14.

[9] PUTRA, G. D., SUMARYONO, S., \& WIDYAWAN, W. (2018). Rancang Bangun Identity and Access Management IoT Berbasis KSI dan Permissioned Blockchain. Jurnal Nasional Teknik Elektro dan Teknologi Informasi, 7(4), 384-390.

[10] RAHARDJA, U.,AINI, Q., ARIESSANTI, H. D., \& KHOIRUNISA, A. (2018). Pengaruh Gamifikasi pada iDu (iLearning Education) dalam Meningkatkan Motivasi Belajar Mahasiswa. Nusantara Journal of Computers and its Applications, 3(2).

[11] RAHARDJA, U.,AINI, Q., GRAHA, Y. I., \& KHOIRUNISA, A. (2019, May). Implementation of Gamification into Management of Education for Motivating Learners. In Proceeding Interuniversity Forum for Strengthening Academic Competency (Vol. 1, No. 1, pp. 209-209).

[12] RAHARDJA, U., HARAHAP, E. P., \& PRATIWI, D. I. (2018). Pemanfaatan Rinfo Sheet Sebagai Media Informasi Laporan Penjualan Barang pada Raharja Internet Cafe. Jurnal IImiah Teknologi Informasi Asia, 12(1), 65-74.

[13] RAHARDJA, U., AINI, Q., \& HARDINI, M. (2018). Penerapan Software Akuntansi Online Sebagai Penunjang Pencatatan Laporan Keuangan. SISFOTENIKA, 8(2), 176-187. 
[14] RAHARDJA, U., SUNARYA, P. A.,AINI, Q., \& DEWI, S. R. (2019). Solusi Payment Online Berbasis Cloud Accounting Pada Manajemen Perguruan Tinggi. InfoTekJar: Jurnal Nasional Informatika dan Teknologi Jaringan, 3(2), 9-15.

[15] RAHARDJA, U., TIARA, K., \& WIJAYA, R. I. T. (2014). Penerapan Rinfo Sebagai Media Pendukung Untuk Proses Pembelajaran Pada Perguruan Tinggi Raharja. CCIT Journal, 8(1), 101-115.

[16] SOEMANTRI, S. (2019). Pelatihan Membuat Media Pembelajaran Digital. Aksiologi: Jurnal Pengabdian Kepada Masyarakat, 3(1), 64-69.

[17] TIARA, K., \& NURHAENI, T. (2016). Penerapan Viewboard GO+ Berbasis Yii Sebagai Media Monitoring Pembayaran Mahasiswa. Technomedia Journal, 1(1), 65-77.

[18] TURKANOVIC, M., Hölbl, M., KOSIC, K., HERICKO, M., \& KAMISALIC, A. (2018). EduCTX: A blockchain-based higher education credit platform. IEEE access, 6, 5112-5127.

[19] WIJAYA, M. (2011). Pengembangan model pembelajaran e-learning berbasis web dengan prinsip e-Pedagogy dalam meningkatkan hasil belajar (Doctoral dissertation, Universitas Pendidikan Indonesia.

[20] ZIKRATOV, I., KUZMIN, A., AKIMENKO, V., NICULICHEV, V., \& YALANSKY, L. (2017, April). Ensuring data integrity using blockchain technology. In 2017 20th Conference of Open Innovations Association (FRUCT) (pp. 534-539). IEEE.

[21] Lu, H., Huang, K., Azimi, M., \& Guo, L. (2019). Blockchain technology in the oil and gas industry: Overview of applications, opportunities, challenges and risks. Access IEEE, 7, 41426-41444.

[22] Shahzad, B., \& Crowcroft, J. (2019). Reliable Electronic Voting Using Customized Blockchain Technology. Access IEEE, 7, 24477-24488.

[23] Zheng, W., Zheng, Z., Chen, X., Dai, K., Li, P., \& Chen, R. (2019). NutBaaS: Blockchain Platform as a Service. Access IEEE, 7, 134422-134433.

[24] Rahardja, U., Lutfiani, N., Lestari, AD, \& Manurung, EBP (2019). Raharja Era University Innovation in Disruptive Using iLearning Methodology. Asian Scientific Information Technology Journal, 13 (1), 23-34.

[25] Umeh, J. (2016). Blockchain double bubble or double trouble? Itnow, 58 (1), 58-61. 